\title{
THE SUGGESTIONS AS TO THE CALCULATION BEARING CAPACITY OF SANDWICH REINFORCED CONCRETE - FOAMED CONCRETE FLOOR SLABS
}

\author{
OKSANA LyTVYNiaK*, MYroslava TASHaK
}

\author{
Department of Civil Safety, Lviv Polytechnic National University, 12 St. Bandery Str., Lviv, 79013, Ukraine \\ * corresponding author: lytvyniak.oksana@gmail.com
}

\begin{abstract}
This article presents the results of an experimental research of sandwich reinforced concrete-foamed concrete floor slabs. These floor slabs combine three different materials - normal concrete, foamed concrete and a steel reinforcement. As experimental models six beams with dimensions $L \times b \times h=4200 \times 500 \times 200 \mathrm{~mm}$ were made. Experimental beams were established on two supports (hinged fixed support and hinged movable support). The experimental study of these beams was executed by two concentrated forces in thirds of beam's span. Received results allowed to describe a behaviour of sandwich reinforced concrete-foamed concrete floor slabs under loading. Moreover, these researches allowed to present suggestions regarding calculations of bearing capacity of sandwich reinforced concrete-foamed concrete floor slabs. These suggestions will give an opportunity to use sandwich reinforced concrete-foamed concrete floor slabs in civil engineering and house building.
\end{abstract}

KEYWORDS: sandwich reinforced concrete - foamed concrete floor slab; foamed concrete; calculation by limiting states; reinforced concrete; fiber polypropylene.

\section{INTRODUCTION}

The modern engineering and construction of different buildings and structures are focused on the decrease of the construction duration, the diminution of materials quantity (which is used for the constructional elements of buildings), the creating of energy-efficient and ecological building structures, and also the improvement of technical and economic indices of built edifices. In addition to that, the diversity and multiplicity of solved tasks determine discrete tendencies of scientific investigations. The most considerable tasks are those that ensure a complex solution of scientific investigations. Solving these problems means a decrease of material capacity and the increase of energy-efficient characteristics for construction elements of prefabricated monolithic buildings during a new construction and by carrying out restoration works for the purpose of ensuring the comfort of residents and the duration of a construction. It is possible as a result of an integrated combination of properties of famous and 'new' building materials, and also new constructional solutions on the basis of non-trivial innovative approaches. In this aspect, the focus should be on improving such important constructional element of buildings as reinforced concrete floor slabs. This improvement is possible because of a new combination of traditional materials (e.g. normal concrete) and 'new' materials (e.g. foamed concrete, aerated concrete etc.), which are used not only as a heat insulation material but also as a structural material.

The foamed concrete is a building material, which consists of cement, fine sand, water and foam. Foamed concrete characterizes low weight, sound and thermal isolation, low prices of manufacturing [1]. From year to year, there is an increased scientific interest of constructors in foamed concrete. In particular, Y.H. Mugahed Amran and others [2] studied physical and mechanical characteristics of foamed concrete and the influence of foamed concrete ingredients on its characteristics and its application field. Furthermore, Maheshkumar H. Thakrele 3] researched physical and mechanical characteristics of foamed concrete with sand and without sand. Because foamed concrete is known for its brittleness, M.R. Jones and A. McCarthy [4] investigated foamed concrete with polypropylene fibres that increased its plasticity, tensile strength and decreased its brittleness.

Scientific interest doesn't limit only to researches of physical and mechanical characteristics of foamed concrete. For example, Martin Decky and others [5] investigated foamed concrete as the material for road constructions. Moreover, Rafał Krzywoń and others [6] carried out experimental studies of foamed concrete foundation plates with a reinforcement by basaltic fibres. Also, researches of foamed concrete beams with a reinforcement from different fibres were made [1, 7, 8].

However, considering previous studies of foamed concrete, we suppose that the actual application of foamed concrete in floor slabs would not be only as an insulation material but also as a structural material. In other words, combination of foamed concrete, normal concrete and steel reinforcement allows to create construction, which will have some advantages in comparison with traditional constructions (for example, reinforced concrete floor slabs) 9 . 


\begin{tabular}{cccc}
\hline $\begin{array}{c}\text { Model } \\
\text { of slab }\end{array}$ & $\begin{array}{c}\text { Sizes of slab } \\
L \times b \times h\end{array}$ & $\begin{array}{c}\text { Strength quality } \\
\text { of } \text { normal concrete }\end{array}$ & Density of foamed concrete \\
\hline FS-1.1 & $4200 \times 500 \times 200 \mathrm{~mm}$ & $22-25 \mathrm{MN} / \mathrm{m}^{2}$ & $800 \mathrm{~kg} / \mathrm{m}^{3}$ with fiber polypropylene \\
FS-1.2 & $4200 \times 500 \times 200 \mathrm{~mm}$ & $22-25 \mathrm{MN} / \mathrm{m}^{2}$ & $800 \mathrm{~kg} / \mathrm{m}^{3}$ with fiber polypropylene \\
FS-2.1 & $4200 \times 500 \times 200 \mathrm{~mm}$ & $22-25 \mathrm{MN} / \mathrm{m}^{2}$ & $1000 \mathrm{~kg} / \mathrm{m}^{3}$ \\
FS-2.2 & $4200 \times 500 \times 200 \mathrm{~mm}$ & $22-25 \mathrm{MN} / \mathrm{m}^{2}$ & $1000 \mathrm{~kg} / \mathrm{m}^{3}$ \\
FS-3.1 & $4200 \times 500 \times 200 \mathrm{~mm}$ & $22-25 \mathrm{MN} / \mathrm{m}^{2}$ & $900 \mathrm{~kg} / \mathrm{m}^{3}$ \\
FS-3.2 & $4200 \times 500 \times 200 \mathrm{~mm}$ & $22-25 \mathrm{MN} / \mathrm{m}^{2}$ & $900 \mathrm{~kg} / \mathrm{m}^{3}$ \\
\hline
\end{tabular}

TABLE 1. The specification of sandwich reinforced concrete-foamed concrete floor slabs.
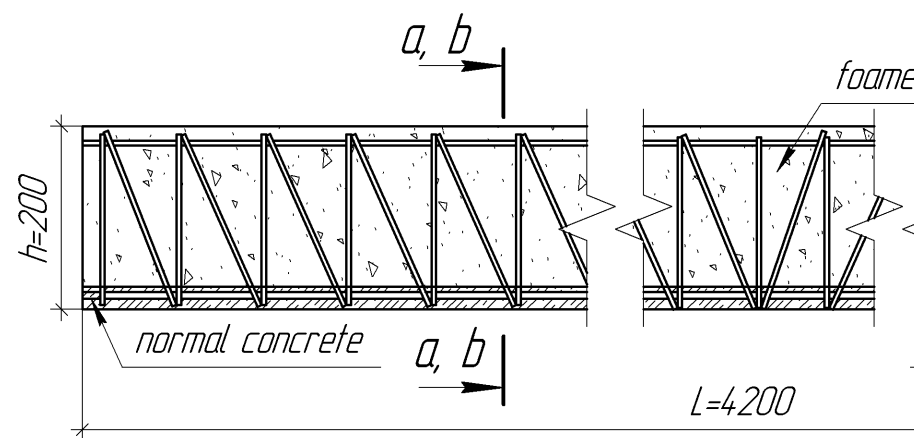
foamed concrete
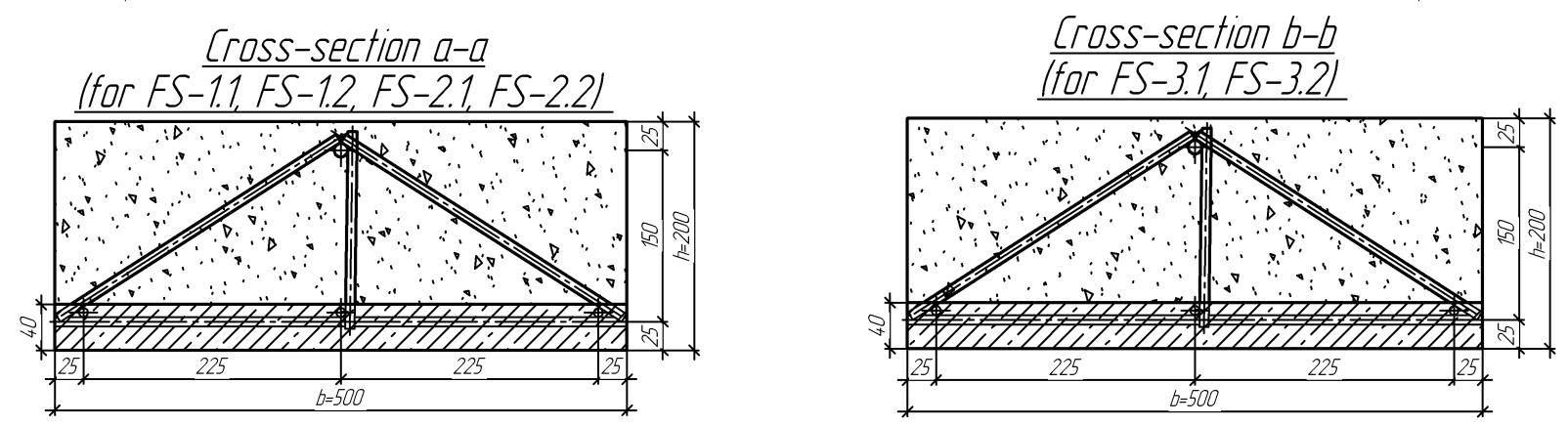

FiguRE 1. Sandwich reinforced concrete-foamed concrete floor slabs.

Nevertheless, the use of sandwich reinforced concrete-foamed concrete floor slabs in civil engineering and house building is possible only by developing design suggestions that are created on the basis of substantiated calculated methods and a determination of the most reasonable method of calculation of sandwich reinforced concrete-foamed concrete floor slabs. The existing analysis, by limiting states of floor slabs, don't allow to appraise, with sufficient accuracy, the bearing capacity of these floor slabs. And, also, the existing calculation methods don't allow to take into consideration the combined work of normal concrete, foamed concrete and steel reinforcement. It is important to note that active standards concerns mainly calculation of only reinforced concrete floor slabs, therefore it isn't possible to estimate the work of foamed concrete constructions under the loading [10]. This state calls for the development of scientific substantiated recommendations, which were received on the basis of realized experimental researches. These researches ensure a creating of accounting treatment by limiting states, which is adapted for an application by designing of sandwich reinforced concrete-foamed concrete floor slabs.

\section{MAterials AND METHOdS}

Sandwich reinforced concrete-foamed concrete floor slabs (SRFCS) are slabs, which are created from normal concrete and foamed concrete. It is possible by including, in the structure of foamed concrete, a dispersed reinforcement by fibre polypropylene for the increase of physical and mechanical characteristics of foamed concrete. The normal concrete and the foamed concrete are jointed with each other by combined spatial reinforcing frame in the form of trihedral prism.

The manufacturing of SRFCS is carried out in two stages. During the first stage, framework slabs (which are combined of normal concrete and spatial reinforcing framework) are produced in a fabricating yard. During the second stage, framework slabs are set up in building edifices densely one by one and concreting of its top part is realized. Due to this, the foamed concrete occupies reinforcing framework and this action allows to create a solid composite construction of a floor slab. The normal concrete of SRFCS fulfils the function of a stationary deck form for the foamed concrete. 


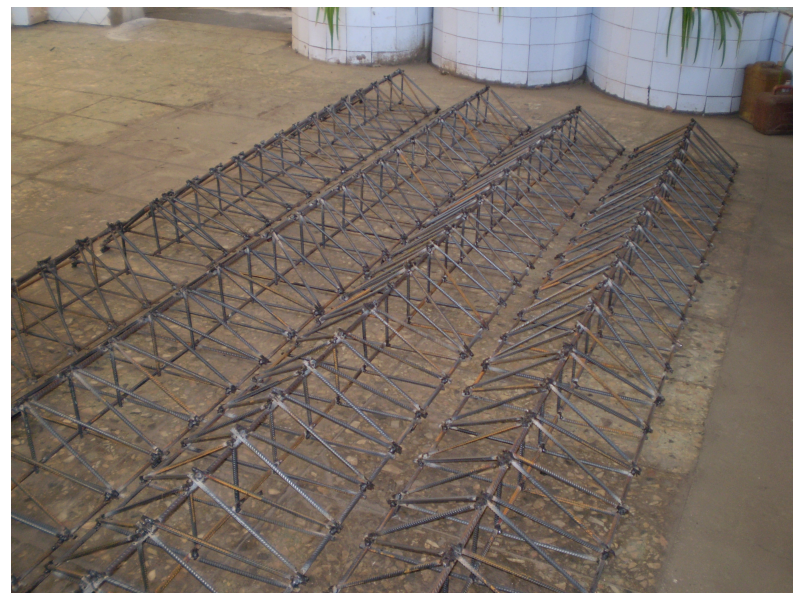

FiguRE 2. The look of spatial reinforcement frames of sandwich reinforced concrete-foamed concrete floor slabs after manufacturing.

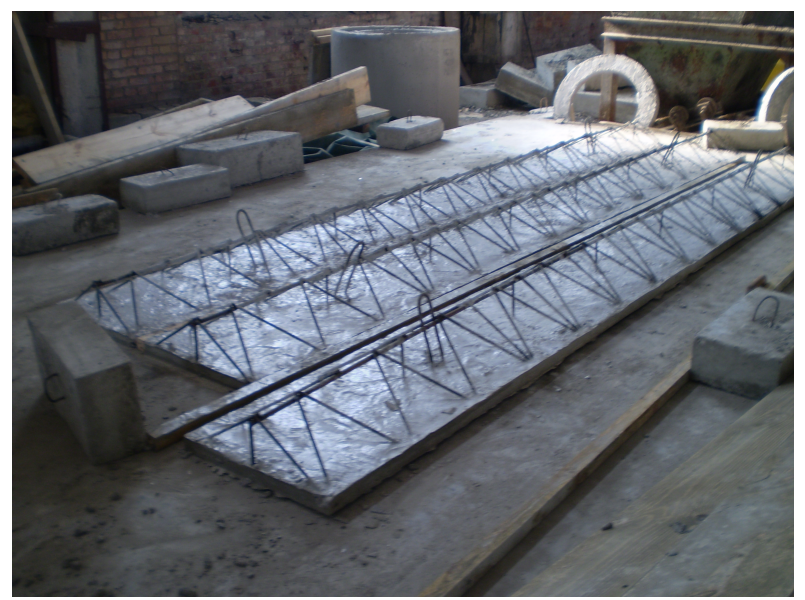

Figure 3. The look of framework slabs after manufacturing.

Six slabs of the SRFCS were manufactured for the development of the calculation method. The characteristic of the research of the SRFCS is presented in Table 1 .

The reinforcement of all experimental models was in a shape of a trihedral prism of reinforcement bars. The top and lower longitudinal reinforcement bars of the spatial reinforcement frame were linked with each other by transversal reinforcement bars. After that, orthogonal and triangular sides were created. The joining of the reinforcement bars was executed by arc welding (Figure 1). Spatial reinforcement frame as trihedral prism was chosen for ensuring of its stiffness.

After manufacturing of the spatial reinforcement frame (Figure 2), its lower side was established in a wooden mould (its height was $40 \mathrm{~mm}$ ) and concreting by normal concrete (strength quality of concrete was $22-25 \mathrm{MN} / \mathrm{m}^{2}$ ) was carried out. The normal concrete was made of cement, sand, broken stone, water and plasticizer C-3. This plasticizer allowed to increase the flowability of the concrete and the water resistance of concrete.

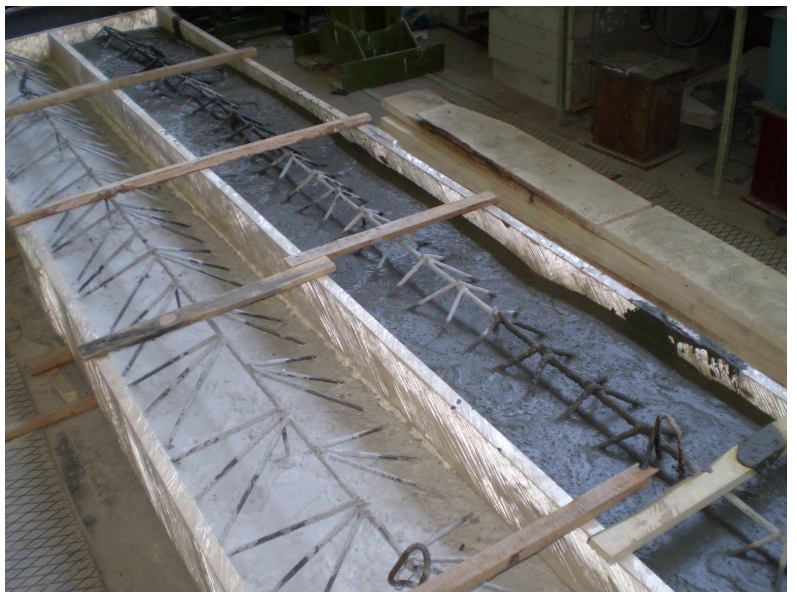

FiguRE 4. The look of sandwich reinforced concretefoamed concrete floor slabs during concrete casting by foamed concrete or foamed concrete with fibre polypropylene.

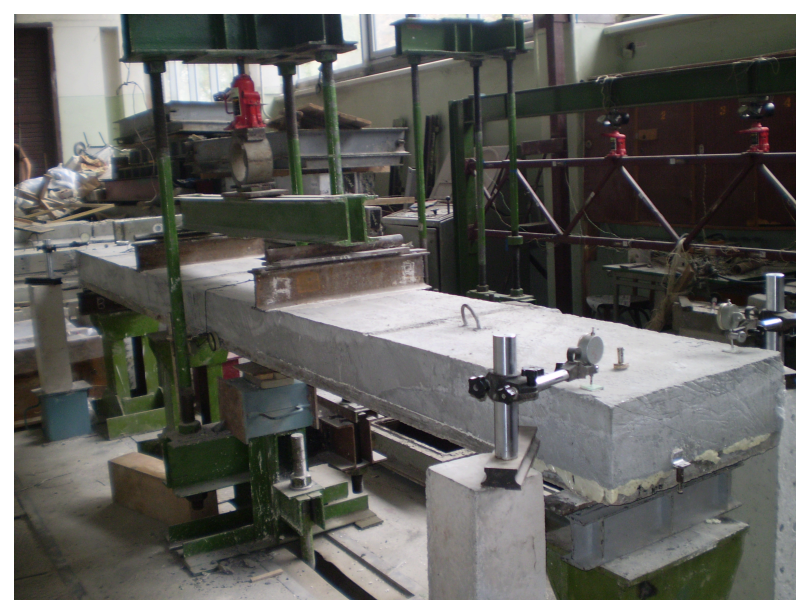

Figure 5. The look of experimental facility during study of sandwich reinforced concrete-foamed concrete floor slabs.

The keeping by normal concrete was carried out from the moment of the concrete's placement. The concrete thickening happened in normal temperaturehumidity conditions. The wooden mould was disassembled after 28 days of concrete thickening.

The manufacturing of spatial reinforcement frame and concrete casting of framework slabs (Figure 3) were executed on the enterprise of building constructions in Lviv.

After that, framework slabs were laid in the wooden mould and concreting by foamed concrete or foamed concrete with fibre polypropylene was carried out (Figure 4).

The foamed concrete was manufactured of cement, fine sand, water and foam. The foam was created by foaming agent of Centripor SK 120 by «BAUCHEMI». The density of the foamed concrete was in the range of $800-1000 \mathrm{~kg} / \mathrm{m}^{3}$.

The foamed concrete beams FS-1.1 and FS-1.2 wre additionally reinforced by fibre polypropylene (density of polypropylene fibre was $900 \mathrm{~kg} / \mathrm{m}^{3}$ ). 


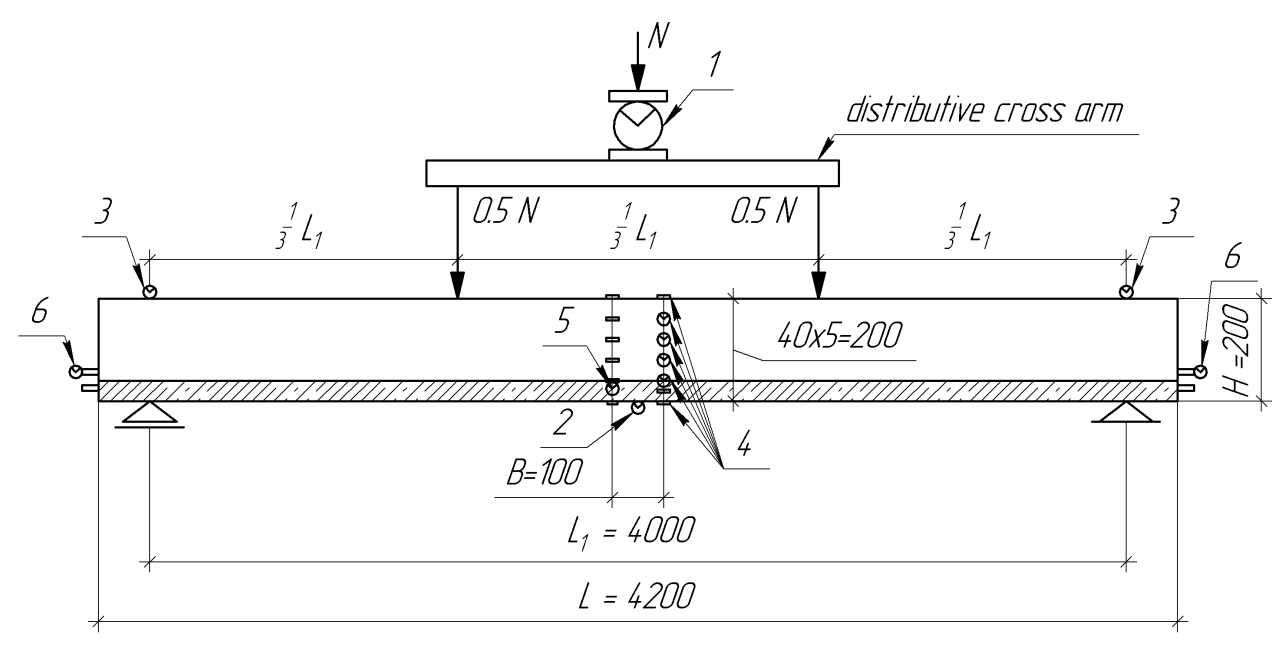

FIGURE 6. The test circuit of sandwich reinforced concrete-foamed concrete floor slabs on bending: 1 - dynamometer; 2 - flexometer (deflectometer); 3 - indicators for measuring by depression of supports; 4 - microindicators for measuring of relative deformations of normal concrete and foamed concrete; 5 - microindicator for measuring of relative deformations of lower longitudinal steel reinforcement; 6 - microindicators for measuring of probable dislocation of foamed concrete relatively normal concrete.

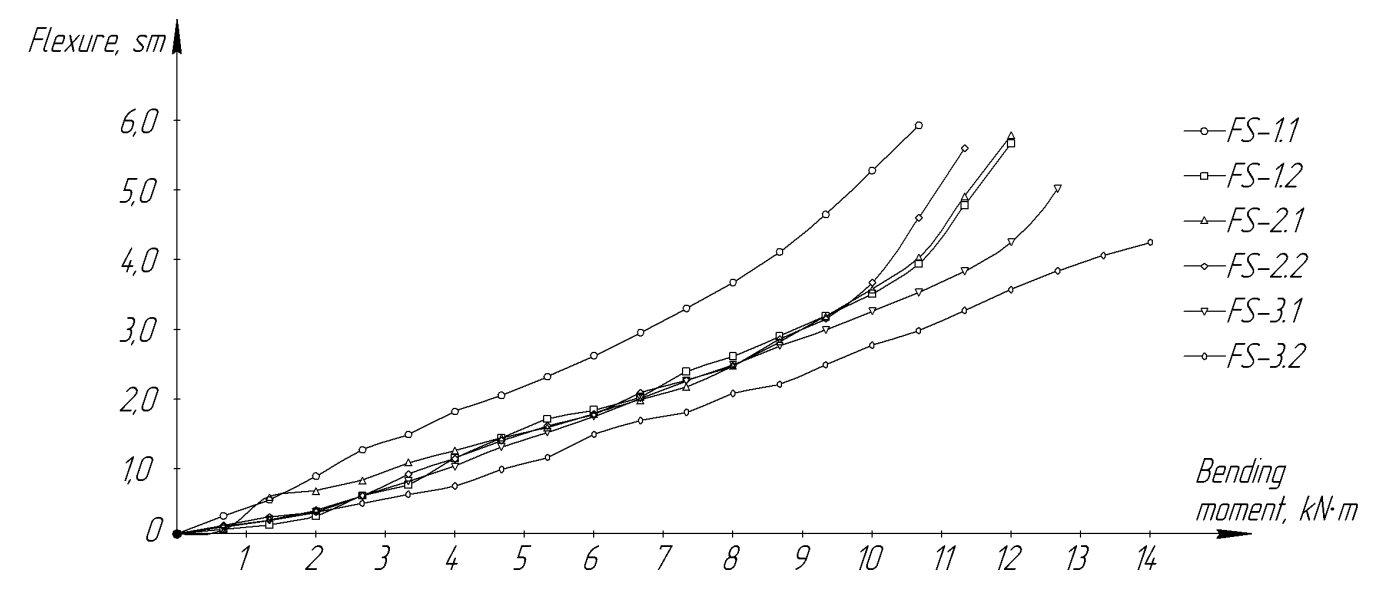

FiguRE 7. Experimental relations 'bending moment - flexure'.

Manufacturing of foamed concrete consisted of the following. First, there was blended cement, fine sand and water in the concrete mixer. After that, water and foam agent were passed under pressure through a foam generator. Afterwards, the foam was mixed with sand-cement mix in the concrete mixer. Fibre polypropylene was added in the created foamed concrete mix and it was mixed in the concrete mixer for 15-20 minutes. The thickening of the foamed concrete lasted 28 days in normal temperature-humidity conditions.

An experimental research of the deflected mode of the SRFCS was realized on the basis of the test procedure of a beam on pure bending. The researched slab was set up on two supports - hinged fixed support and hinged movable support (Figure 5 and 6.

The loading was applied to the researched slab by using a hydraulic jack. The value $\mathrm{N}$ of each load was discrete and it was $1 \mathrm{kN}$. The load was symmetrically distributed on the thirds of the slab's span through a distribution cross arm, with a value of $0.5 \mathrm{~N}[9$.

\section{RESUltS AND DISCUSSION}

The experimental studies done allowed a determination of the following features of the SRFCS. First cracks in the SRFCS appeared in its lower side, i.e. in the reinforced concrete part of slab. The spacing of transversal cracks on the lower side in all slabs coincided with the spacing of the structural transverse reinforcement. An increase of the load caused the appearance of first cracks in the foamed concrete on the lateral sides of the slab. Next, the opening of existent cracks, the appearance of new cracks and the increase of slab deflection took place.

The formation of cracks on lateral sides of the SRFCS (i.e. in foamed concrete) was particularly extended between places of loading. Shear deformations in a contact of two different concretes weren't shown, i.e. SRFCS worked as a monolayer slab.

The destruction of the SRFCS, where foamed concrete had an additional reinforcement by the fibre polypropylene happened gradually. In other words, 


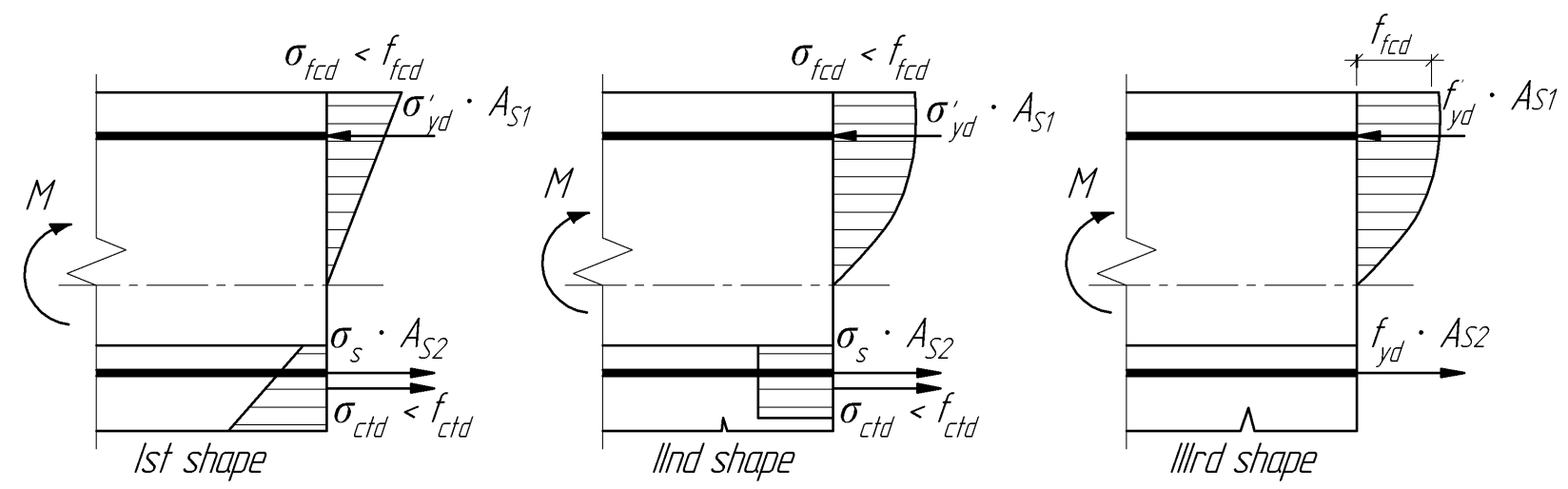

FIGURE 8. The shapes of stressed-deformed state in normal section by bending of sandwich reinforced concrete-foamed concrete floor slabs $[9$.

the fibre polypropylene influences critical coefficients of the stress intensity [11.

And also, experimental relations 'bending moment - flexure' of SRFCS in according to results of its experimental studies (Figure 7) were discovered.

According to the results of experimental researches, it was determined that the test slab was consistently in a stressed-deformed state, which corresponds to three forms of equilibrium by its calculated cross-section, during the load of the test slab by outer forces from the initial value to the breaking value (Figure 8] 9].

1st shape of stressed-deformed state. The deformations of materials (normal concrete, foamed concrete and steel reinforcement) had an elastic character. Normal stress diagrams of compressed zone of the foamed concrete and normal stress diagrams of the tensile zone of normal concrete were similar to triangular. As a consequence of the increase of the outer loading on normal concrete (it was in the tensile zone), a gradual increase of the relative tensile deformations up to the elasticity limit of the normal concrete was observed.

2nd shape of stressed-deformed state. It accompanies the active creation and development of cracks in normal concrete of the tensile zone. In a cross-sections, where the cracks initiated, inner tensile force was taken by the lower longitudinal steel reinforcement and normal concrete of the tensile zone over cracks. The adhesion between the tensile steel reinforcement and normal concrete created sections between cracks. The diagram of the normal tensile stress in normal concrete had a square shape. The inner pressure load was taken by the top longitudinal steel reinforcement and the foamed concrete. The growth of outer loading led to a gradual increase of relative stress deformations up to the elasticity limit of foamed concrete, which was in the compressed zone. The stress compression diagram of foamed concrete had a curvilinear character. In addition to that, ordinate of maximum stress gradually displaced from the border of the calculated cross-section to its middle.
The rise of loading led to a gradual increase of relative deformations in the lower longitudinal steel reinforcement up to the elasticity limit in this reinforcement.

3rd shape of stressed-deformed state. The further increase of the outer loading caused the fact that the stress in the lower part of slab (i.e. in longitudinal steel reinforcement) reached the physical or conditional limit of liquidity and the stress reached á temporary resistance of the axial tension in normal concrete. The increase of the stress in the lower longitudinal steel reinforcement caused the increase of the slab deflection and the decrease of the height of the compression zone that led to an appearance of the limiting state, which was concluded by a destruction of sandwich reinforced concrete-foamed concrete floor slab.

The determination of the bearing capacity on bending of the SRFCS is proposed to be on the basis of the calculation of the limit bending moment, at which the destruction of floor slab happened.

So, the calculation of the bearing capacity on bending by limiting states of the SRFCS is proposed to be done using the equilibrium condition of the inner forces in the calculated cross-section of the floor slab for the 3rd shape of the stressed-deformed state (Figure 9).

The calculation of the stressed-formed state of the SRFCS is done on the basis of following preconditions:

- the condition of combined work of normal concrete, foamed concrete and steel reinforcement and this situation was ensured in the experiment;

- impartial Bernoulli's hypothesis for plane sections is taken into consideration;

- the curvilinear stress diagram of foamed concrete (as parabola) is changed for the equivalent bilinear diagram (orthogonal-triangular) [12] and the work of foamed concrete, which is in the tensile zone (this precondition is used for slabs with foamed concrete of density $900 \mathrm{~kg} / \mathrm{m}^{3}, 1000 \mathrm{~kg} / \mathrm{m}^{3}$ and $800 \mathrm{~kg} / \mathrm{m}^{3}$ with fibre polypropylene) is not taken into account; 

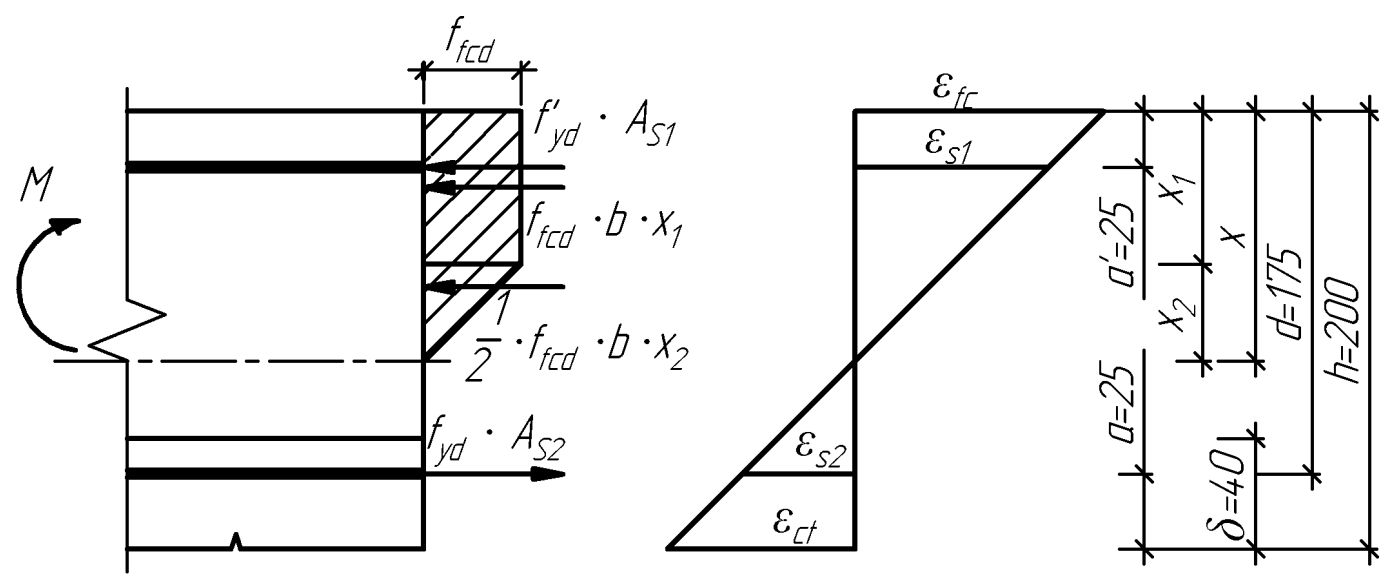

FigURE 9. The scheme of forces in the calculation of bearing capacity of sandwich reinforced concrete-foamed concrete floor slabs 9 .

- the deformations of the top compressed zone of foamed concrete and lower tensile zone of lower longitudinal steel reinforcement are found within a horizontal section of the deformation curve of these materials [13]:

$$
\varepsilon_{\mathrm{fcd}} \leq \varepsilon_{\mathrm{fc}} \leq \varepsilon_{\mathrm{fcu}} ; \quad \varepsilon_{\mathrm{s} 0} \leq \varepsilon_{\mathrm{s}} \leq \varepsilon_{\mathrm{su}} .
$$

According to the accepted preconditions of the calculation, it is determined that a stress in the top of the compressed zone of foamed concrete is equal to the calculated compression strength of foamed concrete $f_{\text {fcd }}$, a stress in the top steel reinforcement is equal to the calculated compression strength of the reinforcement $f_{\mathrm{yd}}^{\prime}$, a stress in the lower longitudinal steel reinforcement is equal to the calculated tensile strength of the reinforcement $f_{\mathrm{yd}}$.

On the basis of suggestions that are shown in [13, the height of the compressed zone of foamed concrete is determined by the equilibrium equation of the inner longitudinal forces in the cross-section of the floor slab:

$$
f_{\mathrm{yd}} A_{\mathrm{S} 2}=\gamma_{\mathrm{fc}} f_{\mathrm{fcd}} b x_{1}+\frac{1}{2} \gamma f_{\mathrm{fcd}} b x_{2}+\gamma_{\mathrm{s} 9} f_{\mathrm{yd}}^{\prime} A_{\mathrm{S} 1},
$$

where $x_{1}$ - the height of the orthogonal part of compressed zone of foamed concrete; $x_{2}$ - the height of the triangular part of the compressed zone of foamed concrete; $f_{\text {fcd }}$ - the calculated prism compressed strength of foamed concrete; $f_{\mathrm{yd}}$ - the calculated tensile strength of the lower longitudinal steel reinforcement; $f_{\mathrm{yd}}^{\prime}$ - the calculated compressed strength of the top longitudinal steel reinforcement; $A_{\mathrm{S} 1}$ - the area of the cross-section of the top steel reinforcement; $A_{\mathrm{S} 2}$ - the area of the cross-section of the lower steel reinforcement; $b$ - the width of the cross-section of the SRFCS; $\delta$ - the height of the normal concrete in the SRFCS.

The correlation between the values $x_{1}$ and $x_{2}$ is expressed by a state diagram of the deformation of foamed concrete (Figure 99:

$$
\frac{x_{1}}{x_{2}}=\frac{\varepsilon_{\mathrm{fcu}}-\varepsilon_{\mathrm{fcd}}}{\varepsilon_{\mathrm{fcd}}}=\frac{\varepsilon_{\mathrm{fcu}}-\frac{f_{\mathrm{fcd}}}{E_{\mathrm{fc}}}}{\frac{f_{\mathrm{fcd}}}{E_{\mathrm{fc}}}},
$$

where $E_{\mathrm{fc}}$ - the modulus of elasticity of foamed concrete; $\varepsilon_{\mathrm{fcd}}-$ the relative compression deformations of foamed concrete by the calculated compression strength of foamed concrete; $\varepsilon_{\mathrm{fcu}}$ - the relative limiting compression deformations of foamed concrete.

The values $\varepsilon_{\mathrm{fcu}}$ are experimentally determined by the bending test of the SRFCS by demonstrations of microindicators, which were placed on the top side of each experimental slab (Figure 5 and 6).

The calculated prism compression strength of foamed concrete $f_{\text {fcd }}$, the modulus of elasticity for foamed concrete $E_{\mathrm{fc}}$, the calculated tensile strength of the lower longitudinal steel reinforcement $f_{\mathrm{yd}}$ and the calculated compression strength of the top longitudinal steel reinforcement $f_{\mathrm{yd}}^{\prime}$ were received by experimental researches of physical-mechanical characteristics of foamed concrete and steel reinforcement.

From the formulas (1)-(3), we recieve the ratio for the determination of the height of the rectangular $\left(x_{1}\right)$ and the triangular $\left(x_{2}\right)$ parts of the compressed zone of the foamed concrete in the rectangular cross-section:

$$
\begin{gathered}
x_{1}=\frac{2\left(\varepsilon_{\mathrm{fcu}} E_{\mathrm{fc}}-f_{\mathrm{fcd}}\right)\left(f_{\mathrm{yd}} A_{\mathrm{S} 2}-f_{\mathrm{yd}}^{\prime} A_{\mathrm{S} 1}\right)}{f_{\mathrm{fcd}} b\left(2 \varepsilon_{\mathrm{fcu}} E_{\mathrm{fc}}-f_{\mathrm{fcd}}\right)}, \\
x_{2}=\frac{2\left(f_{\mathrm{yd}} A_{\mathrm{S} 2}-f_{\mathrm{yd}}^{\prime} A_{\mathrm{S} 1}\right)}{b\left(2 \varepsilon_{\mathrm{fcu}} E_{\mathrm{fc}}-f_{\mathrm{fcd}}\right)} .
\end{gathered}
$$

The bearing capacity of the calculated orthogonal cross-section of the SRFCS can be represented in the following form (by using the bilinear diagram of inner efforts in the compressed zone of foamed concrete, the formulas (1)-(5) and the scheme of forces in the calculated cross-section (Figure 9) :

$$
\begin{aligned}
& M_{A} \leq f_{\mathrm{yd}}^{\prime} A_{\mathrm{S} 1}\left(h-a^{\prime}\right) \\
& +\frac{2\left(\varepsilon_{\mathrm{fcu}} E_{\mathrm{fc}}-f_{\mathrm{fcd}}\right)\left(f_{\mathrm{yd}} A_{\mathrm{S} 2}-f_{\mathrm{yd}}^{\prime} A_{\mathrm{S} 1}\right)}{2 \varepsilon_{\mathrm{fcu}} E_{\mathrm{fc}}-f_{\mathrm{fcd}}} \\
& \quad \times\left(h-\frac{2\left(\varepsilon_{\mathrm{fcu}} E_{\mathrm{fc}}-f_{\mathrm{fcd}}\right)\left(f_{\mathrm{yd}} A_{\mathrm{S} 2}-f_{\mathrm{yd}}^{\prime} A_{\mathrm{S} 1}\right)}{f_{\mathrm{fcd}} b\left(2 \varepsilon_{\mathrm{fcu}} E_{\mathrm{fc}}-f_{\mathrm{fcd}}\right)}\right)
\end{aligned}
$$




\begin{tabular}{cccccccccc}
\hline $\begin{array}{c}\text { Grade } \\
\text { of slab }\end{array}$ & $\begin{array}{c}f_{\mathrm{yd}} \\
(\mathrm{MPa})\end{array}$ & $\begin{array}{c}f_{\mathrm{yd}}^{\prime} \\
(\mathrm{MPa})\end{array}$ & $\begin{array}{c}f_{\mathrm{fcd}} \\
(\mathrm{MPa})\end{array}$ & $\varepsilon_{\mathrm{fc}}$ & $\begin{array}{c}x_{1} \\
(\mathrm{sm})\end{array}$ & $\begin{array}{c}x_{2} \\
(\mathrm{sm})\end{array}$ & $\begin{array}{c}M_{\mathrm{u}}^{\text {theor }} \\
(\mathrm{kNm})\end{array}$ & $\begin{array}{c}M_{\mathrm{u}}^{\text {ex }} \\
(\mathrm{kNm})\end{array}$ & $\Delta=\frac{M_{\mathrm{u}}^{\text {ex }}}{M_{\mathrm{u}}^{\text {theor }}}$ \\
\hline FS-1.1 & 348.65 & 287.43 & 0.94 & 0.00435 & 4.32 & 1.35 & 9.83 & 10.67 & 1.09 \\
FS-1.2 & 348.65 & 287.43 & 1.00 & 0.00285 & 3.57 & 2.24 & 9.86 & 12 & 1.22 \\
FS-2.1 & 348.65 & 287.43 & 1.33 & 0.00411 & 3.11 & 0.85 & 1.05 & 12 & 1.19 \\
FS-2.2 & 348.65 & 287.43 & 1.55 & 0.00374 & 2.55 & 0.93 & 10.14 & 11.33 & 1.12 \\
FS-3.1 & 338.22 & 289.88 & 0.98 & 0.00280 & 10.64 & 6.11 & 12.49 & 12.67 & 1.02 \\
FS-3.2 & 338.22 & 289.88 & 1.07 & 0.00328 & 7.75 & 3.40 & 13.95 & 14 & 1.01 \\
\hline
\end{tabular}

TABLE 2. The comparison of experimental and theoretical -- empirical data of calculation of bearing capacity of sandwich reinforced concrete-foamed concrete floor slabs.

$$
\begin{aligned}
& +\frac{f_{\mathrm{fcd}}\left(f_{\mathrm{yd}} A_{\mathrm{S} 2}-f_{\mathrm{yd}}^{\prime} A_{\mathrm{S} 1}\right)}{2 \varepsilon_{\mathrm{fcu}} E_{\mathrm{fc}}-f_{\mathrm{fcd}}} \\
& \times\left(h-x_{1}-\frac{2\left(\varepsilon_{\mathrm{fcu}} E_{\mathrm{fc}}-f_{\mathrm{fcd}}\right)\left(f_{\mathrm{yd}} A_{\mathrm{S} 2}-f_{\mathrm{yd}}^{\prime} A_{\mathrm{S} 1}\right)}{3 b\left(2 \varepsilon_{\mathrm{fcu}} E_{\mathrm{fc}}-f_{\mathrm{fcd}}\right)}\right) \\
& -f_{\mathrm{yd}} A_{\mathrm{S} 2} a .
\end{aligned}
$$

The comparison of calculated results, which were received by the developed method and the results of the experimental research of the SRFCS is shown in Table 2 there the following symbols are used: $M_{\mathrm{u}}^{\text {theor }}$ - the limiting bending moment, which was received by a suggested calculation of the bearing capacity of the SRFCS; $M_{\mathrm{u}}^{\mathrm{ex}}$ - the limiting bending moment, which was obtained by the experimental research of bearing capacity of the SRFCS.

Obtained results indicate that the suggested method of calculation using the limiting stages of the bearing capacity of the SRFCS satisfactorily agrees with the received experimental data. The difference of the calculated theoretical-empirical data and the experimental data of the SRFCS is within the range of $1-22 \%$.

The realized experimental research and directed methods of calculation of the bearing capacity of the SRFCS give an opportunity to use these constructions in civil engineering and house building. It gives an impulse to create a new qualitative buildings and edifices, which ensure accomplishment of modern demands regarding energy-savings and ecological compatibility and appropriate comfort for residents. Which would be done through the result of corresponding properties of qualitative combination of traditional materials (normal concrete) and 'new' porous building materials (foamed concrete).

\section{Conclusions}

The sandwich reinforced concrete-foamed concrete floor slabs comprise normal concrete, foamed concrete and steel reinforcement. The bearing capacity calculation of sandwich reinforced concrete-foamed concrete floor slabs allows the determination of the limiting bending moment, which causes destruction of this floor slab. The proposed method of the calculation of the bearing capacity of sandwich reinforced concrete-foamed concrete floor slabs by limiting stages satisfactorily agrees with experimental results, the deviation of the theoretical data and experimental data is in the range of $1-22 \%$.

The use of proposed sandwich reinforced concretefoamed concrete floor slabs in civil engineering and house construction allows to realize the manufacturing of framework floor slabs by line production, allowing a decrease of costs of its production by using existing production capacity, mechanization and automation means. These actions allow to divide the labour between corresponding specialties and professions, and also to determine the production capacity. In other words, the use of sandwich reinforced concrete-foamed concrete floor slabs in engineering can become a motive force for the following development in the construction industry.

\section{REFERENCES}

[1] Suhad M. Abd, Dhamyaa Ghalib. Flexural behaviour of lightweight foamed concrete beams reinforced with GFRP bars. Civil Engineering Journal (CEJ) Vol. 4, No. 2 (2018): 278-293.

[2] Y.H. Mugahed Amran, Nima Farzadnia, A.A. Abang Ali. Properties and applications of foamed concrete; a review. Construction and Building Materials 101 (2015) 990-1005.

[3] Maheshkumar H. Thakrele. Experimental Study on Foamed Concrete. International Journal of Civil, Structural, Environmental and Infrastructure Engineering Research and Development (IJCSEIERD) Vol. 4, Issue 1, Feb. 2014, 145-158.

[4] M.R. Jones and A. McCarthy. Preliminary views on the potential of foamed concrete as a structural material. Magazine of Concrete Research, 2005, 57, No. 1, February, 21-31.

[5] Martin Decky, Marian Drusa, Katarina Zgutova, Matej Blasko, Matej Hajek, Walter Scherfel. Foam Concrete as New Material in Road Constructions. World Multidisciplinary Civil Engineering-ArchitectureUrban Planning Symposium 2016 (WMCEAU 2016). Procedia Enginering 161 (2016): 428-433.

[6] Rafał Krzywoń, Jacek Hulimka, Agnieszka Jędrzejewska. Techniczne możliwości zbrojenia pianobetowych płyt fundamentowych. Czasopismo Inżynerii Lądowej, środowiska i Architektury (Journal of Civil Engineering, Environment and Architecture) t. XXXIV, z. 64 (3/1/17), lipiec-wrzesień 2017, s. 341-350, DOI:10.7862/rb.2017.127 
[7] Mochammad Afifuddin, Abdullah, Muhammad Churrany. Shear behavior of fiber foam reinforced concrete beams. Sustainable Civil Engineering Structures and Construction Materials, SCESCM 2016. Procedia Enginering 171 (2017): 994-1001.

[8] Wan Ibrahim M.H., Jamaludin N., Irwan J.M., Ramadhansyan P.J., Suraya Hani A. Compressive and Flexural Strength of Foamed Concrete Containing Polyolefin Fibers. Advanced Materials Research Vol. 911 (2014) pp. 489-493. DOI:10.4028/www.scientific.net/AMR.911.489

[9] Lytvyniak O. Міцність і деформативність збірно-монолітних залізобетонних плит перекриття з використанням пінобетону (Strength and deformability of collapsible monolithic reinforced concrete slabs ceiling with using foamed concrete), Ph.D. thesis, Lviv, 2015 (In Ukrainian).
[10] EN 1992-2:2004. Eurocode 2: Design of concrete structures, 2004.

[11] Solodkyy S. Тріщиностійкість бетонів на модифікованих цементах (Fracture strength concrete on modified cements) Lviv, 2008. 144p. (in Ukrainian)

[12] Murashov V. Трещиноустойчивость, жесткость и прочность железобетона (Fracture strength, inflexibility and reinforced concrete strength), Машстройиздат, 1968 (In Russian)

[13] Краткие заметки о расчете железобетонных конструкций на действие изгибающих моментов и продольных сил (Brief notes about calculation of reinforced concrete constructions on activity bending moments and longitudinal forces), Moscow, 2008 (In Russian) URL:

http://www.ohranatruda.ru/ot_biblio/normativ/ data_normativ/53/53725/index.php [2018-02-01]. 